\section{SOI: $1.1 / \mathrm{TAS} \quad$ DOI: $10.15863 / \mathrm{TAS}$ International Scientific Journal Theoretical \& Applied Science}

p-ISSN: 2308-4944 (print)

e-ISSN: 2409-0085 (online)

Year: 2015

Issue: 09

Volume: 29

Published: 30.09 .2015
Dr. Fadyia Mahdi Alameedy

Lecturer, doctor in virology Faculty of Science, Department of Biology, University of Kufa, Iraq Fadyiam.alameedy@uokufa.edu.iq

SECTION 11. Biology. Ecology. Veterinary.

\title{
EVALUATION OF PROINFLAMMATORY OF HUMAN RHINOVIRUS
}

Abstract: This study was conducted on 96 patients from Abdul Sahib Dakeel health center in the province of Najaf during the period from December 2014 to February 2015, the month was the purpose of this study was to evaluate proinflammatory (IL-6 and IL-18), for patients than controls (18 year) who ranged age patients between (15-45 year) were divided into two age ranges (15-30 and 31-45) year. The virus was isolated from nasal secretions for the purpose of diagnosis of the virus in two ways (rapid test and real time pcr) in addition to the blood samples to assess the proinflammatory (IL-6 and IL-18). Seventy eight case of the study showed that the positive samples of percentage (81.25\%) and eighteen case was negative percentage (18.75\%) is through examination (rapid test and real time pcr) and examination of the nasal secretions. While the results of the proinflammatory showed a very large rise in the level of probability $(P<0.05)$ of each of (IL6 and IL18) in the serum of patients, The study showed a high concentration of IL-6 and IL-18 on the seventh day compared to the results after two weeks and three weeks compared with the control group.

Key words: RT-PCR, IL-6, IL-18, RNA, VP1, VP2, VP3 , VP4, IL-1, IL-17, TNF-a IL-4, IL-10, IL-13, IL-2, ICAM-1, VCAM-1, GM-CSF, TH2, Tcells.

Language: English

Citation: Alameedy FM (2015) EVALUATION OF PROINFLAMMATORY OF HUMAN RHINOVIRUS. ISJ Theoretical \& Applied Science 09 (29): 12-16.

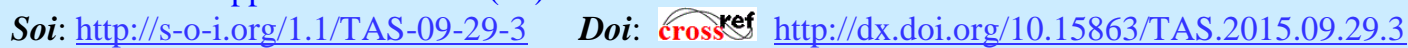

\section{Introduction}

Human Rhinovirus was associated with acute exacerbations of chronic respiratory disease. The viral proteins were transcribed as a single, long polypeptide, which is cleaved into the structural and nonstructural viral proteins. A single-stranded positive sense RNA genomes of between 7.2 and $8.5 \mathrm{~kb}$ in length. At the 5 ' end of the genome was a virus-encoded protein, and like mammalian mRNA, there is a $3^{\prime}$ poly-A tail. Structural proteins were encoded in the $5^{\prime}$ region of the genome and non structural at the 3' end. This was the same for all picornaviruses. The viral particles themselves were not enveloped and were icosahedral in structure.[1]

Human rhinoviruses were composed of a capsid, that contains four viral proteins VP1, VP2, VP3 and VP4. VP1, VP2, and VP3 form the major part of the protein capsid. Sixty copies of each of these proteins assembled as an icosahedron. [2,3]

Human rhinovirus of primary route of the entry was the upper respiratory tract (mouth and nose). Cell lysis occurs at the upper respiratory epithelium.
This virus occurs worldwide and is the primary cause of common colds. The symptoms including sore throat, runny nose, nasal congestion, sneezing and cough; sometimes accompanied by muscle aches, fatigue, malaise, headache, muscle weakness, or loss of appetite. [3]

The infection occurs rapidly, with the virus adhering to surface receptors within 15 minutes of entering the respiratory tract. High risk individuals includes children and the elderly. Just over $50 \%$ of individuals will experience symptoms within 2 days of infection. Only about 5\% of cases will have an incubation period of less than 20 hours, and, at the other extreme, it is expected that $5 \%$ of cases would have an incubation period of greater than four and a half days.[ 4] 
IL-6 is a member of the IL-6-type family of cytokines, whichincludes leukemia inhibitor factor, ciliary neurotrophic factor, and oncostatin-M. Its receptor consists of an IL-6-binding chain) IL-6Ra) and the signal-inducing component (gp130). IL-6R exists in membrane-bound and soluble forms.[5]

IL-6 is a multifunctional, pleiotropic cytokine involved in regulation of immune responses, acutephase responses, hematopoiesis, and inflammation. It is produced by endothelial cells, fibroblasts, monocytes, and macrophages in response to different stimuli (IL-1, IL-17, and TNF-a) during systemic inflammation. In innate immunity, IL-6 directs leukocyte trafficking and activation and induces production of acute-phase proteins by hepatocytes. [6] IL-6 promotesT-cell proliferation, B-cell differentiation and survival, andplasma-cell production of IgG, IgA, and IgM. [ 7]

IL-18 is a member of the IL-1 family that promotes the production of various proinflammatory mediators and plays a role in cancer and various infectious diseases. It was originally identified as IFN--inducing factor and is produced by cells of bothhematopoietic and nonhematopoietic lineages, including macrophages, dendriticcells, intestinal epithelial cells, synovial fibroblasts, keratinocytes, Kupffer cells, microglial cells and osteoblasts. The production of IL-18 is structurally homologousto that of IL-1 ;it is produced as an inactive precursor of 24 $\mathrm{kDa}$, which lacks asignal peptide [6].

IL-18 also induces IL-4, IL-10 and IL-13 production, increases IgE expression on B cells and in association with IL-2, it enhances stimulusinduced IL-4 productionfrom TH2cells. Bone marrow-derived basophils produce IL- 4 and IL-13 in responseto a stimulus from IL-18 and IL-3. IL-18 in combination with IL-12 induces IFN-from dendritic cells and bone marrow-derived macrophages. Adhesion molecules, ICAM-1 and VCAM-1, are induced by this cytokine on synovial fibroblasts and endothelial cells. It inhibits osteoclast formation via its induction of GM-CSF fromT cells. The receptors of IL-18, IL-18Rand IL-18R, share their signaling mechanisms via the IL-1R family. Toll-like receptors also share the downstream signaling pathway of IL18 and are known to regulate IL-18 expression.[7]

IL-18 plays a critical role in host defense against bacterial, viral, fungal and protozoan infections. One predominant mechanism is the induction of host IFN-production, which activates several effector pathways including nitric oxide production, resulting in the clearance of the invading pathogens. For viral infections, the effects of IL-18 are mediated not only via IFN-but also by activation of $\mathrm{CD}^{+} \mathrm{T}$ cells. IL-18 binding protein (IL-18 BP) is the naturallyoccurring antagonist that may serve as a negative feedback mechanism for IL-18 asseveral isoforms of this antagonist have been identified. [ 8]

\section{Material and Methods}

\subsection{Samples Collection}

This study was isolated of human Rhinovirus during a period extended from 15 December 2014 upto 15 of February 2015. A total of 78(45 (57.69\%) females and $33(42.30 \%)$ males) with infected patients in age ranged between (15-45) years of clinical samples were randomly. Specimens were prepared according to Lennette, (1995) and OIE,(2009).

\subsection{Detection of Rhinovirus}

Two different diagnostic procedures were used for detection of Rhinovirus including, rapid device test (CerTestSpain), [9] and real time PCR using the primer design viral RNA kit (primer design UK) in accordance with the manufacturer's instruction successfully amplified. ( Table.1).

\subsection{Evaluation of Pro inflammatory ( IL- 6 and IL-18) \\ Have been diagnosed with the Rhinovirus, as} mentioned in the steps for each kit of (Cat. Number: SEA079Hu and SEA064Hu, Uscn Life Science, U.S.A).

\subsection{Statistical analysis}

The analyses were performed by using one-way ANOVA through the SPSS ( statistical package for social science) program (version-19) and Excel application.

\section{Results}

\subsection{Rapid Test}

A total (96) different clinical cases collected, only 78 cases were positive while (18) negative as detected by rapid test in figure( 1 ). The age ranged between (15-45) years old divided into two groups. Twenty case of (15-35) years fifty six case of (36$45)$ years, compared with control group as in figure (2 and 3 ). 


\begin{tabular}{|c|c|c|c|c|c|c|}
\hline Impact Factor: & $\begin{array}{l}\text { ISRA (India) } \\
\text { ISI (Dubai, UAE } \\
\text { GIF (Australia) } \\
\text { JIF }\end{array}$ & $\begin{array}{l}=1.344 \\
=0.829 \\
=0.356 \\
=1.500\end{array}$ & $\begin{array}{l}\text { SIS (USA) } \\
\text { PИHЦ (Russia) } \\
\text { ESJI (KZ) } \\
\text { SJIF (Morocco) }\end{array}$ & $\begin{array}{l}=0.912 \\
=0.179 \\
=1.042 \\
=2.031\end{array}$ & ICV (Poland) & $=6.630$ \\
\hline
\end{tabular}

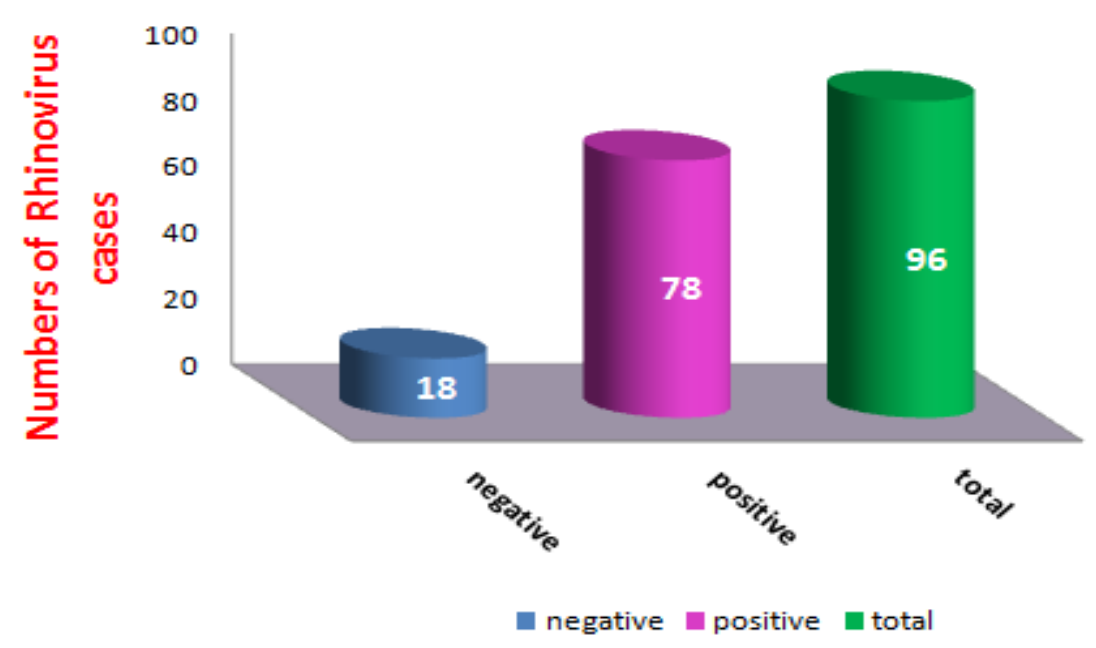

Figure 1- Diagnosis of Rhinovirus by Rapid Test of Numbers of Cases Infected.

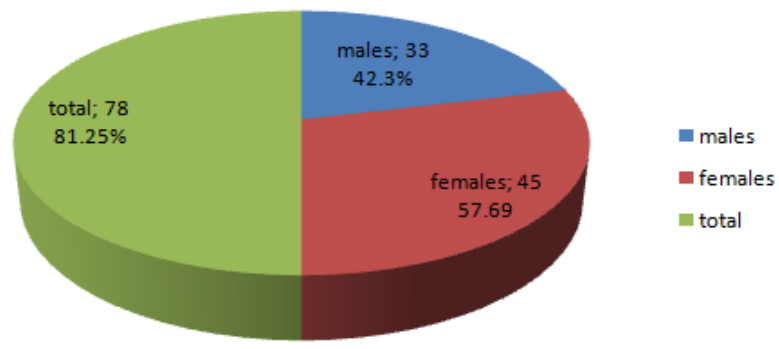

Figure 2- The distribution of patients according to gender groups and presentation.

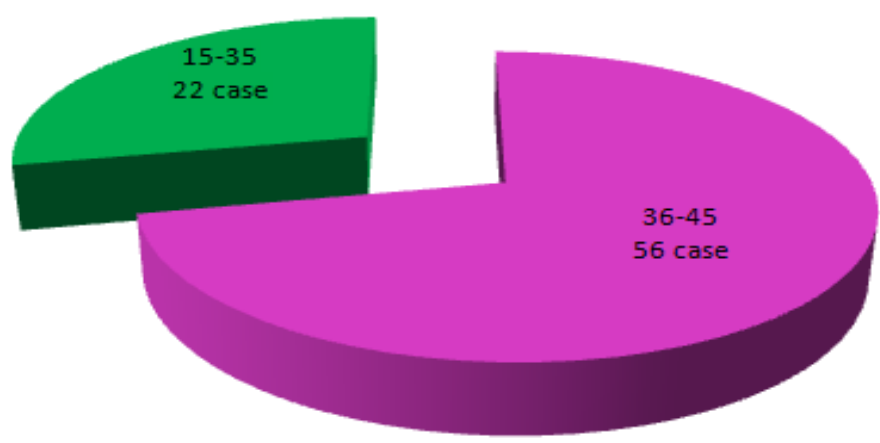

Figure 3- The distribution of patients according to age groups and presentation .

\subsection{Real Time PCR}

Of a total 96 suspected of virus infected cases only 78 positive case were detected as Rhinovirus infected with rapid test device. All the positive cases were undergone diagnosis with real -time - technique in figure(4). 


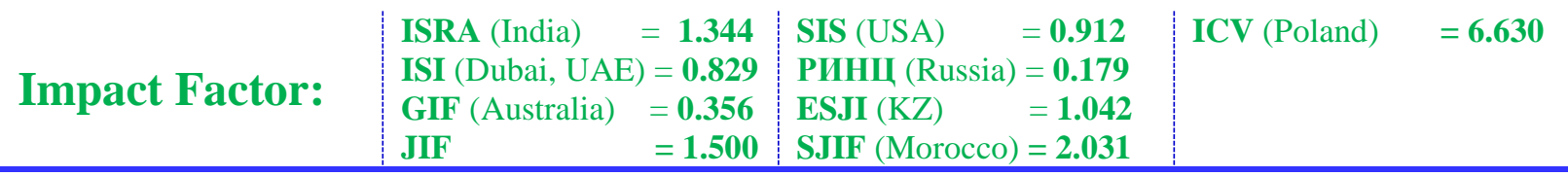

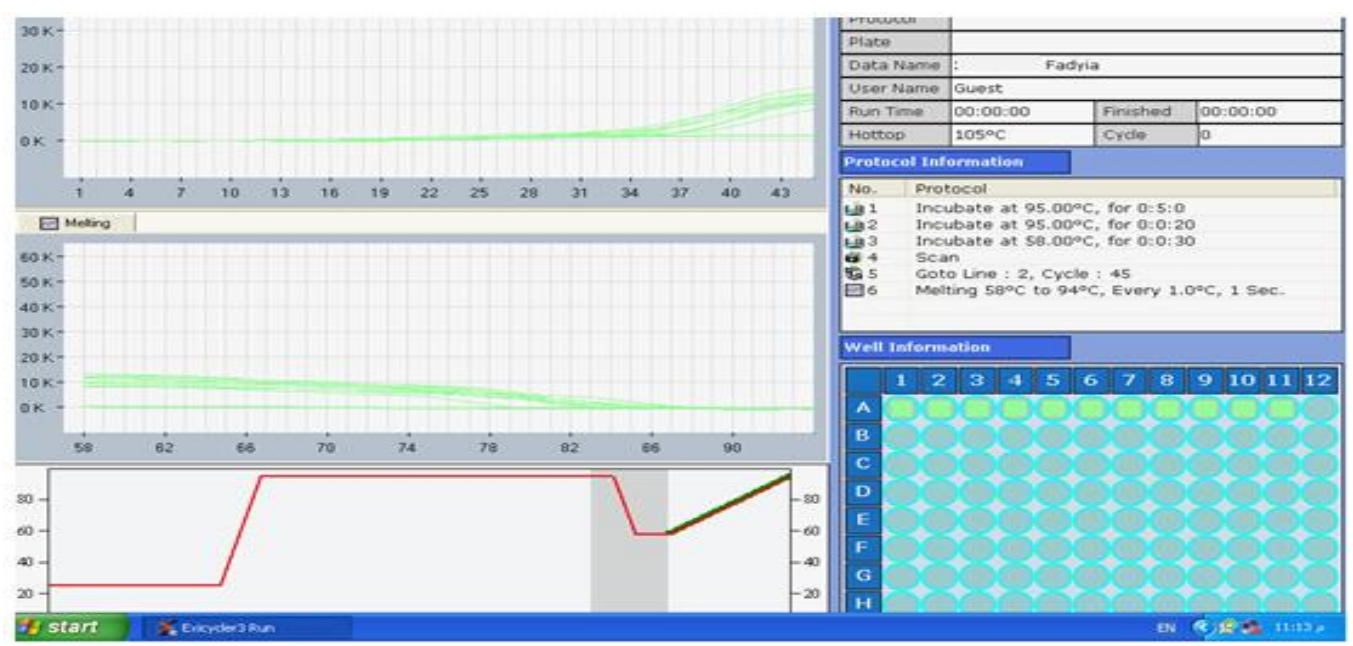

Figure 4- Detection of Rhinovirus by Real time PCR.

3.3.ELISA assay of human proinflammatory (IL-6 and IL-18).

The present study revealed marked increase in proinflammatory (IL-6 and IL-18) in sera of infected patients with the control . The IL-6 and IL-18 were a marked increase the peak values after the seven day $(1.344 \pm 0.28 \mathrm{pg} / \mathrm{ml}$ and $1.356 \pm$ $0.22 \mathrm{pg} / \mathrm{ml}$ ) and after fourteen and twenty one day $(1.328 \pm 0.29 \mathrm{pg} / \mathrm{ml}$ and $1.320 \pm 0.31 \mathrm{pg} / \mathrm{ml})$ respectively in comparison with the control value of $(0.616 \pm 0.18)$.

IL-18 was a marked increase in the level of patients group comparison with the IL-6 which reached its peak after fourteen, twenty one day $(1.347 \pm 0.26 \mathrm{pg} / \mathrm{ml} 1.341 \pm 0.29 \mathrm{pg} / \mathrm{ml})$ of infected patients respectively than the control group (Table 2).

Mean titers of proinflammatory IL-6 and IL-18 of infection patients.

\begin{tabular}{|c|c|c|c|c|}
\hline Proinflammatory & Groups and number & 7 day & 14 day & 21 day \\
\hline 㤐 & Infected (n.78) & $1.344 \pm 0.28$ & $1.328 \pm 0.29$ & $1.320 \pm 0.31$ \\
\hline$\stackrel{\infty}{\stackrel{1}{G}}$ & Infected (n.78) & $1.356 \pm 0.22$ & $1.347 \pm 0.26$ & $1.341 \pm 0.29$ \\
\hline 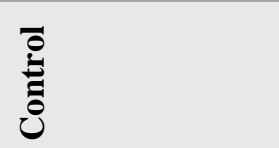 & Healthy human (n.18) & $0.616 \pm 0.18$ & $0.616 \pm 0.18$ & $0.616 \pm 0.18$ \\
\hline
\end{tabular}

\section{Discussion}

The samples of Rhinovirus was collected from nasal secretion, and sera of patients, this results agreed with that found by Jacobs,et al.,(2013); Costa et al.,(2014). Among ages 36-45 years, more vulnerable to infection during the study appeared to be independent of age. The study showed the percentage of females $(57.69 \%)$ are more affected than males $(42.30 \%)$, results also were in agreement with other studies, documented by (Zlateva et al., 2014). Leung et al.,(2001) and Chen et al., (2007) were found that levels of IL-6 and IL-18 appear to increase of level titer. 


\begin{tabular}{|c|c|c|c|c|c|c|}
\hline Impact Factor: & $\begin{array}{l}\text { ISRA (India) } \\
\text { ISI (Dubai, UAF } \\
\text { GIF (Australia) } \\
\text { JIF }\end{array}$ & $\begin{array}{l}=1.344 \\
=\mathbf{0 . 8 2 9} \\
=\mathbf{0 . 3 5 6} \\
=1.500\end{array}$ & $\begin{array}{l}\text { SIS (USA) } \\
\text { PИHЦ (Russia) } \\
\text { ESJI (KZ) } \\
\text { SJIF (Morocco) }\end{array}$ & $\begin{array}{l}=0.912 \\
=0.179 \\
=1.042 \\
=2.031\end{array}$ & ICV (Poland) & $=6.630$ \\
\hline
\end{tabular}

\section{References:}

1. Rossmann M, Arnold E, Erickson J, Frankenberger E, Griffith J, Hecht H, Johnson J, Kamer G, Luo M, Mosser A (1985) "Structure of a human common cold virus and functional relationship to other picornaviruses". Nature 317 (6033): 145-53.

2. Smith T, Kremer M, Luo M, Vriend G, Arnold E, Kamer G, Rossmann M, McKinlay M, Diana G, Otto M (1986) "The site of attachment in Human rhinovirus 14 for antiviral agents that inhibit uncoating". Science 233 (4770): 128693.

3. Fuji Naoko, Suzuki Akira, Lupisan Socorro, Sombrero Lydia, Galang Hazel, Kamigaki Taro, Tamaki Raita, Saito Mariko, Aniceto Rapunzel, Olveda Remigio, Oshitani Hitoshi (2011) Schulz, Thomas F, ed. "Detection of human rhinovirus $\mathrm{C}$ viral Genome in blood among children with severe respiratory infections in the Philippines".PLoS One 6 (11): e27247.

4. Suzukawa M, Iikura M, Koketsu R, Nagase H, Tamura C, Komiya A, et al. (2008) An IL-1 cytokine member, IL-33, induces human basophil activation via its ST2 receptor. J Immunol 2008;181:5981-9.

5. Suzukawa M, Koketsu R, Iikura M, Nakae S, Matsumoto K, Nagase H, et al. (2008) Interleukin-33 enhances adhesion, CD11b expression and survival in human eosinophils. Lab Invest 2008;88:1245-53.

6. Cherry WB, Yoon J, Bartemes KR, Iijima K, Kita H (2008) A novel IL-1 family cytokine, IL-33, potently activates human eosinophils. J Allergy Clin Immunol 2008; 121:1484-90.

7. Gross O, Yazdi AS, Thomas CJ, Masin M, Heinz LX, et al. (2012) Inflammasome activators induce interleukin-1alpha secretion via distinct pathways with differential requirement for the protease function of caspase-1. Immunity 36: 388-400.

8. Weinberg A, Walker ML (2013) Clinical and Diagnostic Labor-atory Immunology", 12(3), 367-370. 200510- Jacobs, S.E.; Lamson, D.M.; St, G.K.; Walsh, T.J. Human rhinoviruses. Clin. Microbiol. Rev. 2013, 26, 135-162.

9. Costa LF, Queiroz DA, Lopes da Silveira H, Bernardino Neto M, de Paula NT, Oliveira TF, Tolardo AL, Yokosawa J (2014) Human rhinovirus and disease severity in children. Pediatrics. 2014;133:e312-21 Lessler J, Reich NG, Brookmeyer R, Perl TM, Nelson KE, Cummings DAT.; Reich; Brookmeyer; Perl; Nelson; Cummings (2009). "Incubation periods of acute respiratory viral infections: a systematic review". Lancet ID 9 (5): 291-300.

10. Zlateva KT, de Vries JJ, Coenjaerts FE, van Loon AM, Verheij T, Little P, Butler CC, Goossens H, Ieven M, Claas EC (2014) Prolonged shedding of rhinovirus and reinfection in adults with respiratory tract illness. Eur. Respir. J. 2014, 44, 169-177.

11. Leung BP, Culshaw S, Gracie JA, Hunter D, Canetti CA, et al. (2001) A role for IL-18 in neutrophil activation. J Immunol 167: 28792886.

12. Chen CJ, Kono H, Golenbock D, Reed G, Akira S, et al. (2007) Identification of a key pathway required for the sterile inflammatory response triggered by dying cells. Nat Med 13: 851-856. 